\title{
MEZEY Gyula
}

\section{VÁLSÁGDÖNTÉSEK ÉS A JÖVÖ ELŐREJELZÉSE}

Válsághelyzetben a döntéshozóknak gyorsan kell dönteniük, hogy lépést tudjanak tartani a gyorsan változó és általában sok bizonytalanságot (információhiány, illetve ellentmondó információk tömege) tartalmazó helyzettel. Ezek a döntések azonban kockázatosak. Ezeknek a kockázatoknak a mérsékléséhez és a konfliktusok minél gyorsabb és kielégítőbb kezeléséhez ad elméleti és gyakorlati segítséget a szerző.

Bonyolult szituációkban a döntéshozók, akiknek emberi tudása és információ-feldolgozó képessége korlátozott, tipikusan nem az optimális megoldást keresik, hanem megelégszenek már egy kielégítő megoldással is, viszont törekszenek a bizonytalanság minimalizálására.

A kockázatos döntések osztályába tartoznak azok a döntési helyzetek, ahol ismert mindegyik cselekvési alternatíva kimeneti értéke, és az alternatívák valószínűsége is - azaz a döntéshozó informáltsága tökéletes (hát mi akkor itt a kockázat?) ${ }^{1}$. Az ún. bizonytalan döntések osztályába tartoznak például a válságkezelés olyan jellegzetes esetei, amikor az időkorlát, a stressz vagy a vezető behatárolt tudása és informáltsága miatt egy kielégítő megoldási alternatíván kívül a többi egyébként szóba jöhető - változattal komolyan már nem is tudnak foglalkozni. A bizonytalanság minimalizálását emellett még a döntés hatásainak visszacsatolása és néhány kulcsfontosságú (pl. biztonságpolitikai stb.) jellemző értékének adott tűrésmezőn belül tartása szolgálják.

Alapvető az a feltevés, hogy a bizonytalanságot kontrollálni tudjuk. A döntéshozónak ehhez nem kell sem döntési alternatívák kimeneti értékeinek, sem újabb és újabb valószínűségi értékek kalkulálásával foglalkoznia: e tevékenységeket elvégzi helyette egy programozott automata: a számítógép. Azt remélték, hogy jobb eredményeket fognak kapni, ha ennek az automatának a segítségével szimulációkat végeznek akár abból a célból, hogy az ellenfelek közül az egyiknek a döntéseihez tanácsot adjanak, például az ellenfél magatartá- sát figyelembe vevő javaslatot készítsen egy számítógép. A döntéstámogató rendszer (DSS Decision Support System) akkor új fogalmát ${ }^{2}$ ilyen és hasonló problémákat megoldó rendszerek megkülönböztetésére vezették be $^{3}$.

Konfliktuskezeléskor természetes az, hogy előrejelzésre, az ellenfél várható magatartásának becslésére törekszünk, hiszen ez csökkenti bizonytalanságunkat ${ }^{4}$. A cikk további részében foglalkozunk is előrejelzésre alkalmas módszerekkel. Előre kell bocsátani, hogy a játékelmélet hagyományos ${ }^{5}$, kvantitatív modelljei a gyakorlatban sajnos nem bizonyultak eredményesnek - sem a cselekvési változatok valószínűségeinek, sem az ellenfél haszonfüggvényének becslése valahogy nem ment valós körülmények között ${ }^{6}$.

A döntési modell tehát feltételez egy organizmusra vonatkozó „magatartás-modellt”, egy azon sorozatos szimulációkat végző számítógépes mechanizmust, és a racionalitás alapján állva alkalmazza még a matematikai algoritmusokat is e mechanizmus működtetéséhez. A magatartásmodell megalkotásához van szükség a mesterséges intelligencia (AI) alkalmazására ${ }^{7}$, amelynek főbb - egymással részbeni átfedésben levő - területei pl.:

- robotika,

- adatfúzió,

- természetes nyelv feldolgozása (NLP),

- számítógépes „látás” (CV computer vision),

- tudásalapú rendszerek (KB), illetve ezek egy alfaja: a szakértői rendszer (ES),

- tanuló rendszerek (pl. mesterséges ideghálózat ANN). 
A tudásalapú rendszereknek tanulniuk kellene, különben a bennük kezelt tudás elavul, és ez hibás döntésekhez vezet.

Válsághelyzetben gyorsan kell dönteni, hogy lépést tudjanak tartani a gyorsan változó és általában sok bizonytalanságot (információhiány, illetve ellentmondó információk tömege) tartalmazó helyzettel. A gyűjtött adatokat elemezni és rendszerezni kell ahhoz, hogy a döntéshozókat használható információval lássák $\mathrm{el}^{8}$. A szakértői tudás tárolt formában azonnal rendelkezésre áll, és a régebben alkalmazott megoldásokhoz (decision aid) képest rugalmasabban, gyorsabban módosítható. A modellek átstrukturálása, módosítása, prototípus-készítés gyorsan megy akkor, ha rendelkezésünkre áll egy eszközkészlet (ún. „tool-box”) és egy ún. „kvalitatív” modellt (pl. ES-t) használunk.

\section{Szakértői rendszer (ES)}

A döntéshozó számára különösen akkor fontos a bizonytalanság csökkentése, amikor több szakértője vagy éppen szakértői rendszerei eltérő állásponton vannak a helyzet megítélésében. ${ }^{9}$ Ilyenkor a következő meggondolásokra támaszkodhatna egy a vélemények eredőjét kihámozó ún. „munkatábla” (blackboard) szakértői rendszer ${ }^{10}$ :

\section{Döntések módosítása az új információ figyelembevételével (Bayes-tétel)}

A Bayes-módszer az állítások bizonytalanságával foglalkozik. A kalkulációhoz a Bayes-tételt alkalmazzuk, és a döntéshozó bizonytalanságát még érzékenységvizsgálattal is csökkentjük. Hátrány viszont, hogy nagyon sok elemi esemény valószínűségét kellene a priori ismerni. Ráadásul az, hogy egy döntést módosítani kell-e, függ az újabb és újabb információk megbízhatóságától, ami végül is a döntéshozó szubjektív megítélésétől függ. Új információk beérkezése és a módosítások egy szekvenciális folyamatnak tekinthetők. Valószínűségfát vagy döntési fát alkalmazva az újabb és újabb információk figyelembevételével kalkulált a posteriori valószínűségekkel rendre felcseréljük majd az a priori valószínűségeket . Ez nagy munka, ezért inkább a problémát vagy a „fuzzy-modell”, vagy a ,bizonyíték elmélet” alapján oldják meg.

\section{Dempster - Schafer bizonyitékelmélete}

Ez az elmélet a Bayes-elmélet kiterjesztése, de itt nem elemi eseményekkel, hanem komplett hipotézisekkel foglalkoznak arra fókuszálva, hogy adott állítás bizonyítékai azt milyen bizonyossággal támogatják ${ }^{12}$. Dempster kombinációs képlete aggregálja a független forrásokból származó információt ${ }^{13}$ és nincsen szükség a priori valószínűségekre. Mindez alkalmassá teszi arra, hogy a szakértők álláspontjainak eredőjét segítségével meghatározzuk, akkor, ha a szakértők tudásában nincs átfedés. Ha ilyen átfedés lenne, akkor viszont még a Ling - Rudd szabályt is alkalmazni kell ${ }^{14}$.

\section{Bizonyosságtényezők \\ és a bizalom erösségének mértéke}

Azon esetekben, amikor a bizonytalanságot nem a valószínűségelmélet segítségével írjuk le, a bizalom vagy a kételkedés, illetve az elfogadhatóság erősségével fejezzük ki a döntéshozó bizonytalanságát. Az elmélet ún. bizalom-függvényeket vezet be, és pl. finom különbséget tesznek az ignorálás, az információhiány, a szubjektív észlelésre alapozott ún. „epistemic" információ és a bizonytalanság között. Csoportdöntés vagy szakértői álláspontok eredőjének meghatározása alkalmával is a bizalom erősségével végzünk speciális müveleteket.

Egy konfliktus során a helyzetben beállott változások az eredeti célok megváltoztatásához vezethetnek. Ahogyan előre nem látott szituációk lépnek fel, a fenyegetés és ellen-fenyegetés, a próba-szerencse alapon döntés, visszacsatolás/visszajelzés, szimuláció tipikusan előforduló funkciók a konfliktus-kezelés közben. A numerikus modell axiómákra épül, de sajnos nem enged ún. dinamikus modellezést. A tudásalapú rendszerbe betáplált szabályok (vagy eljárások) által képviselt, axióma nélküli kvalitatív modellek ${ }^{15}$ viszont lehetővé teszik mind a dinamikus modellezést, mind az ún. evolúciós rendszertervezést is ${ }^{16}$. Habár e szabályok a gyakorlatban alkalmazott ún. heurisztikus hibrid rendszerekben kapcsolatban vannak kvantitatív elemekkel (pl. bizonyosságtényezők) is, a modell kvalitatív és alapvetően nem matematikai, hanem szimbolikus formalizmust használ fel.

A rendszer tudásbázisa ${ }^{17}$ vagy egy szakértőnek a szcenáriókhoz kapcsolódó tudását, vagy modellezési és szimulációs eredményeket tartalmaz. Ha egy tudásbázist célszerűen strukturálnak, akkor azt könnyű nagyon gyorsan változtatni, és az új szimulációt lefuttatva gyors eredményt kapni. Például egy szabályban való változtatáshoz csupán egy paramétert kell átállítani.

Ezért is alkalmaznak a konfliktuskezelésen belül az elemzésre (konfliktus-elemzés) általában tudásalapú, illetve a játékelmélet ún. kiterjesztéseire támaszkodó rendszereket.

A játékelmélet kiterjesztéseire épített rendszerek előrejelzés céljára a gyakorlatban eléggé beváltak, és a kiképzésben is hasznosak ${ }^{18}$. Ezek a modellek ugyan föleg kvantitatív adatokra támaszkodnak, és a döntésho- 
zó szabad játéktere főleg a döntési kimenetek közül való választásra, illetve a különböző preferencia-sorrendek szimulációval történő végigpróbálgatására korlátozott.

Ehhez képest a tudásalapú rendszerek esetében a döntéshozónak nagyobb játéktere van, elsősorban a dinamikus modellezés és a gyors prototípus-készítés következtében. Fontos gyakorlati jellemző, hogy például az EFAR szoftver (lásd e cikk végén) egy-két héten belül, míg a tudásalapú rendszer egy-két napon, esetleg néhány órán belül szolgáltat eredményt a modell gyors módosíthatóságához és a prototípus elkészítéséhez ${ }^{19}$.

\section{A kvalitatív modellezés fontossága}

Válságkezelés céljára a tudásbázis tartalmazza a veszélyhelyzeti tervet és a válaszreagáláshoz szükséges tudást, a tervezés, a szervezés és a mozgósítás szakaszaiban hozott korábbi döntéseket. A veszélyhelyzeti tervezéshez pedig célszerűnek bizonyult a következő három funkcionális elem alkalmazása ${ }^{20}$ :

- régebbi katasztrófák alkalmával készített felvételekből eltett videóarchívum, mert ebből a válság, a katasztrófa nagyságára, az ott megoldott dilemmákra és a célok összetett voltára lehet képet kapni,

- egy ún. modell-bázis, ahol a döntések támogatásához lehet kész modellek közül választani,

- egy ún. csoport-eljárások bázisa, ahonnan a csoportdöntésben résztvevők magatartását befolyásoló beavatkozások közül lehet választani.

A válsághelyzetek, katasztrófák történeti példagyűjteménye, kiemelve a felmerült problémák és a megszületett megoldások összefüggéseit, alkalmas lehet arra, hogy ún. esetpélda-alapú következtetést (CBR Case-based reasoning $)^{21}$, vagy mesterséges-ideghálós mintafelismerést (ANN) végezzünk, aminek eredményét (felismert szabályok) viszont szakértői rendszerbe táplálva az potenciálisan segíteni fog későbbi válsághelyzetek hasonló problémáinak megoldásában.

Mindenesetre egy szakértői rendszer folyamatos továbbépítése nagyon munkaigényes. A tudásbázis felépítéséhez szerencsére létrehoztak automatizált megoldásokat is (pl. Auto-intelligence $)^{22}$. Mindamellett általában a szakértói rendszernek nehézséget okoz váratlan, előre nem sejtett esetek megoldása.

\section{A metatudásbázis}

A „metatudás” kifejezésnek szűkebb értelme: a rendszer tudása arról, hogy „saját maga hogyan gondolkodik". A tágabb értelme pedig fedi mindazt, amit a tudásbázis tartalmáról és annak szerkezetéről a rendszer „saját maga tud” ${ }^{\text {23 }}$.
Véleményünk szerint válságkezelés céljára, veszélyhelyzeti tervezéshez a legfontosabb szempontok:

- a különböző vezetési szintekhez rendelt modellek,

- a döntési stratégiák : ezek csoportosíthatóak paradigmák szerint: analitikus, kibernetikus, kognitív, bürokratikus, politikai alku stb,

- vagy más ismérvek szerint, pl. Flin szerint ${ }^{24}$ : kreatív, analitikus, tevékenység/szabályzat, mintafelismerés (RPD recognition primed) alapú stb.

\section{Az információ szintén osztályozható:}

- a válság állapotai/szakaszai,

- a válság hőfoka (pl. a szabályok egy eszkalációs „létra” fokozatai szerint vannak csoportosítva).

A helyzetértékelés hierarchiája:

- országos stratégiai vezetési szint: néhány kulcsváltozó, soft-adatok,

- operatív vezetési szint: közbenső változók, softadatok,

- taktikai vezetési szint: a (pl. térképi) részletes adatok $^{25}$.

\section{Elörejelzési technikák}

- Normatív jellegü technikák, pl:

- döntési mátrix,

- relevancia-fa ${ }^{26}$,

- operációkutatási módszerek ${ }^{27}$ (pl. lineáris programozás, dinamikus programozás).

- Felfedező (exploratory) előrejelzés, pl:

- trend előrevetítés,

- morfológiai elemzés ${ }^{28}$,

- intuitív módszerek (pl. Delfi-módszer),

- gazdasági elemzés (pl. költség-haszon és költséghatékonyság-elemzés),

- játszmák (lásd később),

- modellezés ${ }^{29}$

- szcenárióírás (lásd később),

- feltételhez kötött multiszcenáriók (lásd később).

\section{A trendre épült tervek}

A trend-előrevetítés lépései (a környezetből kívülről-befelé tekintve): $:^{30}$

1. A környezet megfigyelése és trendek észlelése.

2. A fontos releváns trendek kiválasztása, amelyek valószínűleg befolyásolják a jövőt.

3. A fenti trendekből egy jövőkép formálása.

4. A tervezést ezt a jövőképet feltételezve végezzük.

A bizonytalanságot valószínűség-számítással, Monte-Carlo elemzéssel kezeljük. 
Ahhoz, hogy minden egyes döntést egy átfogó cél érdekében hozzanak, ok-okozati visszavezetést használunk $^{31}$. Ennek formája lehet akár egy relevancia-fa, akár egy influencia-diagram is ${ }^{32}$. A gyakorlatban a normatív és a felfedező előrejelzést kombinálni lehet. Azt viszont, hogy egy csoport véleménye a trendek megítélésében egységes legyen, általában nehéz elérni.

\section{Feltételezésekre épített tervezés}

Ez éppen a csoporttagok eltérő véleményeiből adódó problémát kerüli meg: itt nem is szükséges közös nézőpont kialakítása. Egyszerűbb a jelen világ különféle változásait feltételezve előrejelzés-változatokat adni, mint egyetlen jövőképben egyetérteni és abból kiindulva tervezni. A különböző feltételezésekre épített tervezés lépései (belülről a környezet felé haladva):

1. a jelenlegi működés alapjául szolgáló feltételezések behatárolása (pl. dokumentumelemzés és interjúk segítségével),

2. változásokra utaló jelek gyújtése (pl. Delphi-módszerrel szakértői csoport segítségével),

3. olyan változások azonosítása, amelyek felboríthatják a jelenlegi feltételezések érvényét (erre jelenleg nincs szisztematikus eljárás),

4. minden egyes felboruló feltételezéshez egy-egy új „világ” felvázolása (többszörös világkép generálás),

5. ,jelzőpóznák” kifejlesztése, „korlátozó és alakító” intézkedések („korlátozó és alakító” szándékú tervek készítése) $)^{33}$ tervezése.

Az eltérő feltételezésekre épített tervezés igényli a sokféle szcenárió felvázolását, és felfogható úgy is, mintha a csoportdöntés egymás utáni kisebb részekre lenne felbontva. Ez a felfogás jól összevág azzal a jelenséggel, amelyet nagy szervezetek csúcsvezetőségénél tapasztaltak: ,a célokra csak sorjában, célzottan fókuszáló" magatartással ${ }^{34}$. A csúcsvezetés egyszerúen nem képes a középvezetők részcéljai szempontjából alakított és felterjesztett döntési javaslatok célintegrálására, az átfogó célhoz való alakítására, és - „visszautasítja a célok integrálását" ${ }^{\prime 35}$. A csúcsszintű döntés így konzerválja az alacsonyabb vezetői szintről előkészített döntések fregmentáltságát ${ }^{36}$.

A szisztematikus szcenáriókészítéshez a szakirodalom ajánl alkalmas technikákat ${ }^{37}$.

\section{Egy alapvető tételezés - az ,értékintegráció” visszautasítása}

Az eltérő feltételezésekből kiinduló, nagyszámú szcenárióra alapozott döntéstámogatás szándékosan elveti az „értékek integrációját”. Ugyancsak hiányzik az, hogy a világ alternatív állapotait egyetlen ellentmondásmentes preferencia-sorrenddel lehetne jellemezni. Hiszen a felső vezetők csúcskoordinációja sem az értékek integrációjának alapján történik a gyakorlatban. Ezzel szemben a szervezeten belül az előírt eljárásoknak (SOP) formailag nem szabad egymással szembeni ellentmondásokat tartalmazniuk. És ha egyszer a rutineljárások kialakultak, nem könnyű ezeket megváltoztatni.

Ami a döntéshozatalt támogató szimulációs mechanizmust illeti, az egy folyamat végigfuttatásával az elképzelhető kimeneteknek ugyan széles értékkészletét állítja elő, de anélkül, hogy a valóságban majd tényleg bekövetkező helyzetről világos képet adna. Viszont néhány kritikus fontosságú változó visszajelzett állapotát figyelemmel kísérik, monitorozzák. Ilyen körülmények között ahelyett, hogy a döntési probléma egy optimális megoldására törekednének közvetlenül, inkább a széles értékkészletek képviselte változatosságot igyekeznek tűréshatárok közé szorítani, kontrollálni.

Ezt az is indokolja, hogy ritkán előforduló események gyakoriságának szubjektív becslése igen gyenge. De még objektív esetben is, sokszor, amikor egy esemény valószínűségét kalkuláljuk, a gyakorlatban bizonytalanok a tapasztalati adatok (hiszen sok eseményt nem jelentenek), az események következményértékei (egyszerre számos különféle hatás érvényesül és ezeket egymástól nehéz szétválasztani), nehéz a kitettséget előre jelezni, a hatásokat megjósolni, a következményeket felbecsülni, mérni költséget és hasznot a modellek bizonytalanságai (azaz korlátozott tudásunk) miatt.

Ez is oka tehát annak, hogy egy „tanulógép”, egy mechanizmus szelektál ki cselekvési alternatívákat, nem annyira elméleti meggondolások alapján, hanem úgy, hogy a lehetséges jövőképek széles sávját tekintve is kielégítőnek vélt megoldásra vezet” „,robosztus” alternatíva legyen. Azonban a közelmúltig hiányzott az ilyesféle szelekciót segítő szoftvertámogatás, ezért fejlesztették ki pl. a DYNARANK, az @RISK stb. „tool”-okat ${ }^{38}$.

Az inputok változtatására robosztus (kevéssé érzékeny) megoldás csoportdöntéskor igen hasznos: a csoporton belüli vita elcsendesedik akkor, ha azt látják, hogy a tagok egyéni súlyozása a végeredményt tekintve alig számít ${ }^{39}$. Ez pedig a sokkal gyorsabb döntéshozatalt segíti elő - igaz, annak árán, hogy visszafogja az egymással szembenálló egyéni álláspontok ütköztetését. De hát közismert Arrow tétele, miszerint elméletileg lehetetlen egységes csoportvélemény igazán demokratikus kialakítása, tehát egy közös csoportérték vagy egy közös haszon-függvény keresése amúgy is hiábavaló lenne ${ }^{40}$. 
Ennek a fenti döntési mechanizmusnak a tanulási és adaptív képessége akkor érvényesülhetne jól, ha a döntések egy viszonylag stabil környezetben történnének ${ }^{41}$.

A védelmi tervezés kockázat-elutasító karakterű tevékenység, általában a „maximin” döntési kritérium egészséges pesszimizmusa használatos: „válaszd a legelőnyösebbet, de a lehető legrosszabb esetekre számítva" (tehát az utóbbiak közül) ${ }^{42}$. Mindamellett a cél nem a várható érték, vagy a hasznosság maximális értékéhez tartozó alternatívának a kiválasztása ${ }^{43}$, hanem az, hogy a legrobosztusabb vagy egy „még eléggé robosztus" cselekvési alternatívát találjunk. Lélektanilag feltehetően ez a legfontosabb azok számára, akik kockázatos alternatívák közül a viszonylag legbiztosabbat preferálják.

A kedvező jövőképeket mutató szcenáriókhoz csak az fog a valóságban elvezetni, ha az arra vezető lehetőségeket felvillanásukkor azonnal meg is ragadjuk. Egy kedvezőtlen irányba mutató fejlődési utat pedig úgy tudnánk elkerülni, ha egy korai figyelmeztető rendszer kiemelné számunkra ennek a figyelmeztető jeleit. Akkor azonnal be tudnánk avatkozni, hogy elkerüljük a veszélyt.

\section{A jövő feltárása előrejelző és jövőkutató modellekkel}

\section{Az elörejelzö modellek}

A számítógépes modellezés azokon a területeken volt sikeres, ahol a modellre támaszkodó előrejelzéseket a tapasztalat alapján ellenőrizni lehetett, és nyilván kétség maradt ott, ahol nem nyílt mód a modell helyességének, hasznosságának tapasztalati igazolására. Ahol az előrejelzés után annak a bekövetkezett eseményekben megtapasztalt igazolása nem lehetséges, a modell helyességére nézve semmi sem állítható, csak az, hogy ezt nem előrejelző modellnek hívjuk. Ahol a társadalmi modellek előre jelzett viselkedésének tapasztalati alapon való validálása nem megy, ezeket feltáró modelleknek kell tekintenünk. Nem számít az, hogy pl. egy modell milyen részletes, a validálatlan modell csupán a valósághűség illúzióját adja.

A múltbeli megtörtént esetekre támaszkodó modell és a múltbeli tapasztalatokkal való igazolás sem biztos, hogy megfelelő a modell validálásához, mert az események szcenáriófüggőek. A modellvalidálás a társadalomtudományokban eleve igen nehéz. A nem-előrejelző modelleket eltérő módon célszerű kezelnünk a tapasztalattal való egybevágásuk okán validáltnak tekintett előrejelző modellektől.

\section{A feltáró (exploratory) modellek}

A feltárás jelentheti azt, hogy egy rendszer olyan részleteit, amire nincsen adat, becsléssel próbáljuk találgatni. A becsült adatokból akár következtetett adatok is számíthatóak, ami esetleg felfedezésre vezethet (pl. a káoszelméletet úgy fedezték fel, hogy anomáliákat próbáltak szimulálni).

Egy olyan modellnél, amelyet előrejelzőnek tartunk, a validáláshoz az érzékenységvizsgálat is hozzátartozik. Egy feltáró modellnél az érzékenység-elemzés aztán egyenesen nélkülözhetetlen, arra feltétlenül szükségünk van (mindenféle validálástól függetlenül is), mert a kimenetek értékkészletét és annak eloszlását ismernünk kell. A gyakorlatban persze képtelenség ez utóbbiakat minden befolyásoló körülményre kiterjedően meghatározni, - de legalább a rendszer erőforrásai kritikus aspektusaira mintavételes érzékenységvizsgálatot szokás végezni.

A feltáró modellezés akkor lehet sikeres, ha nem átfogó, „nagy” modellt készítünk, melyet sokféle kérdés megválaszolásához használnak, hanem több ,kis” modell készül úgy, hogy egy modellt csak arra készítenek fel, hogy csupán egy kérdésre tudjon választ adni ${ }^{44}$. Így az érzékenységvizsgálat és a modell korrekciója is egyszerűbb. A modell korrekciójára (iteratív újratervezésére és átírására) általában szükség van, hiszen használata során a felhasználó a tapasztaltakból okul, és az így szerzett új tudását a korrekciókkal adja tovább a modellbe. A rendszer bonyolultságát és a környezete bizonytalanságait együttesen egy „modell-család” képviseli.

\section{Előrejelzés, konfliktus- és alkudozáskezelés a játékelmélet kiterjesztéseivel}

A játékelmélet él azzal a feltevéssel, hogy egy konfliktushelyzetet (,játék”) a döntéshozók (,játékosok”) tisztán racionális (a lélektani befolyástól mentes) magatartása irányítja. A klasszikus játékelmélet még azt feltételezte, hogy az egyik játékos nyeresége a másik vesztesége, azaz a játék ,zéró összegü” és hogy a két játékos, mint ellenfélhez illik, egymással nem kooperál ${ }^{45}$. Később az alkudozások és a tárgyalás (először csak két, aztán több játékos között) modellezésekor az együttműködés és az összes játékos nem-konstans nyereségének modellbe illesztését is megoldották ${ }^{46}$. Az együttműködő játékosoknak egymással információcserét kell folytatni, és kötelező erejű, kikényszeríthető megállapodásokat kell kötniük.

A játékelmélet azt feltételezi, hogy a játékosok egymástól eltérő mértékű hasznot húznak a másiktól minden egyes döntésük alkalmával, és ezt az adatot mind 
ismerik $^{47}$. Sajnos a gyakorlatban ezt nehéz elképzelni. Azonban egy gyűlés, pl. egy ún. döntési konferencia, ahol egy döntéselemző specialista müködik közre, megkönnyítheti azt, hogy egyesek veszteségét mások nyereségéből, anélkül kompenzálják (legalább részben), hogy az az együttmúködni kész felek közötti nyílt kenyértörésre vezetne ${ }^{48}$.

A játszma szituációit például az „egyensúly” fogalmával jellemezhetik. Ezt az „egyensúlyt” aztán többféleképp is lehet értelmezni ${ }^{49}$. „Nash-egyensúly” áll fenn akkor, ha egyik játékosnak sem áll érdekében a folytatás, habár képes lenne rá. „Stackelberg-egyensúly" akkor van, ha az egyik játékos mindent tud arról, amit a másik lépett (nincs titkuk egymás előtt). „Pareto-optimum" az a helyzet, amikor egy olyan lépés történik, ami egyik játékost sem hozza rosszabb helyzetbe. „Myoptikus” magatartású játékos nyereségének maximalizálása érdekében nem csak az ellenfelet, de saját magát is ki meri tenni személyes kockázatnak stb.

Az alkuelmélet azt próbálja megmagyarázni, hogy a nemzetközi kapcsolatok racionális döntéshozatala mellett hogyan törhetnek ki mégis háborúk. Ahelyett, hogy csupán a saját álláspontot védenénk mereven, a tárgyalásokra alkalmazott több-attributumú értékelemzés elvezethet az érdekek békés összeegyeztetéséhez (pl. több, konkrét esetben Pareto-optimumot alkalmaztak $)^{50}$. Bizonyíték van arra, hogy mind az állati, mind az emberi döntések - legalábbis bizonyos körülmények között - a racionális döntési modellt követik ${ }^{51}$. A játékelmélet alapján akár egyéni, akár kollektív játékosok stratégiáját, manővereit, alkuit sokszor meg lehet érteni, és magyarázni - de jobbára csak utólag ${ }^{52}$. A jövő előrejelzésére nem annyira a konvencionális játékelmélet, hanem inkább a játékelmélet modern ún. kiterjesztései bizonyultak hasznosabbnak a gyakorlatban. Ezek nem a racionális, hanem a korlátozottan racionális döntési magatartást veszik alapul, azt modellezik. Sőt, a csoportdöntés új modelljeit állítják fel, szakértői teamek véleményeit összegzik stb.

A már előbb említett döntési konferencia egyik gyakorlati nehézsége, hogy az ellenfelek egymáséit kölcsönösen kizáró döntési alternatíváinak kifejtése már egyszerű esetekben is igen nagyszámú cselekvési változathoz vezet. Általában a tárgyalási problémákat jellemzi a néhány cél és a fenti értelemben vett rengeteg cselekvési alternatíva $^{53}$. Ez az oka annak, hogy jól jön a döntéselemzőnek is a szoftvertámogatás (pl. EQUITY), amivel egy kooperáló csoporton belüli kompenzációkat lehet számon tartani és kalkulálni. Ennek alapja egyrészt a hasznok egy közös mérési skálája és egy közös többváltozós haszonfüggvény a csoporton belül $1^{54}$. Egyes esetekben értékfüggvényt lehet alkalmazni.
Egyetértés kialakítása érdekében akár két ellenfél közötti tárgyalás, akár egy együttmúködő csoporton belüli kompenzációk megbeszélése a tét, a többváltozós értékelemzésnek az ún. additív-érték modellje nagyon sokszor bevált technika ${ }^{55}$.

\section{Stratégiai konfliktus döntéstámogatásával szembeni elvárások}

Egy konfliktus akkor stratégiai, ha létfontosságú érdekek forognak kockán. Egy szervezet védelmi, konfliktuskezelési döntései különösen igénylik az elemző előkészítést. Egy stratégiai konfliktus döntéstámogatási rendszerével (DSS) szemben az alábbi elvárások merülnek fe ${ }^{56}$ :

- Feltehető, hogy a felhasznált játékelmélet (vagy annak kiterjesztése) alkalmaz valamilyen ,egyensúlyt”.

- A DSS modellezi azoknak a játékosoknak a hatalmát, képességét, motivációját, akik a játékot irányítani, ellenőrizni tudják. A játék valószínűleg nem zéróösszegű.

- A DSS a játékosok egymástól eltérő hiedelmeit egy négydimenziós térben írja le: racionalitás, cél, struktúra, szándék. A rendszerállapotok közötti kapcsolatok, az egyes rendszerállapotok közötti átmenetek természete az, hogy mi jelent sikert, a megoldás jellege különbözhet az egyes játékosok szemszögéből és még ez is változhat, ahogy a játék menete előrehalad. Az állapotátmenetek rendszerint nem jellemezhetők egyszerűen csak költséggel, vagy az átmenet valószínűségével. Több, egyaránt helytálló álláspont is létezhet akár a konfliktus egész menete alatt. A kimenetek haszonértékeit egy-egy játékos preferenciái szerint lehet rendezni. A lépéseket vagy a tekintélyelv, vagy a fontosabb játékosok személyes befolyása, vagy a sürgős lépéskényszer, vagy a késedelem ára, vagy szankciók vezérlik ${ }^{57}$.

- A változó környezethez való alkalmazkodás (még a célok is változhatnak).

- A DSS-nek hibás, félrevezetô, hiányos adatokat is helyesen kell tudnia feldolgozni.

- Új bizonyíték vagy észlelés az addig elfogadott adatok helyesbítéséhez vezessen.

- A DSS elfogadja akár az egyén, akár a csoport irracionális viselkedését.

- A stratégiai és a taktikai szinten is folyó tárgyalások miatt a modellnek legyen egy kisebb és egy nagyobb felbontású változata a kinagyíthatóság miatt. A lokális (taktikai) optimum az egyszerủ játékelméleti, a globális (stratégiai) optimum keresése pedig a kiterjesztett játékelméleti modelleket használhatja. 
- A konfliktust nem egyoldalúan, pártosan vizsgálja, tehát a rendszer nézőpontja semleges.

- Mind „kemény”, mind „soft” adatokat használni tud.

- A végrehajtott lépések visszafelé is követhetőek.

- Elfogadható annak a társadalmi közegnek a részéről, amelyben múködni fog.

• A már múködő rendszerekkel nem ,ütközik”.

\section{A játékelmélet konfliktuskezelésre alkalmazott kiterjesztései}

A konvencionális játékelmélet a fenti kritériumok közül csak kevésnek tesz eleget, habár konkrét helyzetben és konkrét célra alkalmazását tekintetbe lehet venni. A nemzetközi kapcsolatok terén és a magatartás miatti konfliktus esetében viszont a számítógépi modellezés nehéz lehet. Ugyanez áll fenn a nem játékelméleti alapon végezhető konfliktuselemzésre is, kivéve azonban a tudásalapú rendszereket.

A játékelmélet modern kiterjesztései (VUG, DG, hyperjáték, szuperjáték, Foveal-játék, konfrontációelemzés, drámaelmélet, többféle jövőképtervezés) mutatkoztak úgy, hogy DSS-be valóak, válságelemzésre alkalmasak. Ezek nem „fekete doboz” módszerek, és figyelembe veszik az emberi természetet, azt, hogy a döntések hiedelmeink alapján és vágyainkat követve születnek. Röviden felsorolva, e módszerek köre az alábbi:

\section{„Változó univerzum” játékok csoportja}

(VUG, VUG1, VUG2, VUG3)

A játékosok különböző tudással rendelkeznek a játéktér jellemzőiről és számukra a játék végállapotaihoz különböző kifizetési értékek tartoznak. Kulcsfontosságú az, hogy a játékosoknak eltérő hiedelmei (different belief sets) vannak ${ }^{58}$. A játékosok még a játék struktúrájáról is eltérően vélekedhetnek ${ }^{59}$.

\section{Determinisztikus grafikus játékok (DG, DGT, DGA)}

Diszkrét DG-kre Brams (1994) ad egy taxonómiát ${ }^{60}$ :

DGT (DG terminális) játékok ciklikus gráfokként kezelhetők, de a befejezés nem garantált (zéró kifizetés mellett).

DGA (DG időben átlagolt kifizetéssel) a DGT kiterjesztése, ahol a befejezés garantált (Nash-egyensúly), de a játékos húzásaihoz költségfüggvényt nehéz hozzárendelni. A gyakorlatban probléma, hogy mind a DGT, mind a DGA hiánytalan információ meglétét tételezik $\mathrm{fel}^{61}$.

\section{Szuperjátékok}

Szövetségesek együttmúködésére, illetve árulására vonatkozó döntési helyzeteket kezelnek ${ }^{62}$.

\section{Hyperjátékok}

Flexibilis modellezést tesz lehetővé úgy, hogy a változás-adatok a taktikai és stratégiai szint közötti átvezetését, adatkorrekciót, és „,megbocsátást” alkalmaz ${ }^{63}$.

\section{Metajátékok}

A konfliktus helyzetet leírandó a metajáték a felhasználónak a döntési alternatívák listáját ajánlja fel azzal, hogy törölje azokat, amelyeket kizár, a megmaradókat pedig preferenciája szerinti rangsorba rendezze egy diagramon. Aztán szcenáriókat mutat és a helyzet javulásához vezető lehetséges ,jobbító folyamatokat", amelyekhez költség és haszon tartozik. Emberi érzelmek (pl. harag, gyűlölet stb.) ugyancsak szerepelnek a modellben, amely ajánlásait grafikus formában teszi ${ }^{64}$.

Mind a CAP (konfliktus-elemző), mind a DECISIONMAKER szoftvereket Fraser és Hipel tervezték, esettanulmány-leírások rendelkezésre állnak ${ }^{65}$.

Pusztán egy kedvező alternatívánk melletti döntéssel azonban még nem tudjuk kézben tartani a konfliktust, az ellenfélnek is van döntési szabadsága, és „megfúrhatja" a helyzetünk javítását célzó folyamatot. Gyakorlatban az ilyen folyamat-alternatívák felvázolása előtt az együttmúködő játékosok csoportja egyeztet, és utána készülnek az intézkedési-terv alternatívák ${ }^{66}$. Minden alternatíva minden kimenetéről (előnye/hátránya) minden egyes játékos számára készül egy-egy táblázat. Ha a táblázat nincs teljesen kitöltve, vagy félreérthető, vagy a kvantitatív és kvalitatív jellemzőket nehéz egy nevezőre hozni, akkor az probléma ${ }^{67}$.

A játék számos kimenete lehet metaegyensúlyi pont, azaz minden játékos számára racionális. De úgy, hogy az irracionalitás és a racionalitás közötti átmenetben a racionalitás három fokozatát is megkülönböztetik: racionalitás, szimmetrikus metaracionalitás, általános metaracionalitás ${ }^{68}$.

\section{Konfrontációelemzés és drámaelmélet}

A drámaelmélet a metajáték kiterjesztése, amely a játékosok motivációjának és haszonfüggvényeinek a játék menete közbeni változásait is figyelembe veszi ${ }^{69}$. A dráma nincs előre megírva, hanem a szereplők minden egyes felvonás végén hozott döntéseinek és céljainak (a kívánt végkifejlet) függvényében alakul ${ }^{70}$. A célok eléréséhez a szereplők együttmüködve juthatnak. DSS és alkalmazások rendelkezésre állnak ${ }^{71}$. 


\section{Az Egyesült Királyság „kristálygömbje”}

Politikai, katonai, üzleti stratégiai döntések támogatásához alkalmazzák pl. a FAR, EFAR (foveal-játék), Powergraph, Kora szoftvereket.

\section{Többszörös jövőképtervező (FAR)}

A FAR egy jövőbeli szcenáriókat tervező eszköz ${ }^{72}$. Diszkrét állapotok közötti átmeneteket alkalmazó hálógráfelemző. Inputként szakértők által kitöltött AHP szoftvert használ ${ }^{73}$.

Abból az állapotból, ahol most állunk (a szituációk $\mathrm{N}$-dimenziós terében), egy másik óhajtott (cél) állapotba kívánunk eljutni. A problématér lehetséges jövőbeli szituációi közül egyes állapotok kívánatosak, mások viszont elkerülendők. A FAR kimenete az, hogy ezek az állapotok egy ún. Jövőfa formájában jelennek meg, melynek terminális pontjai a jövőbeli szcenáriók ${ }^{74}$.

A FAR-t regionális fejlődés előrejelzésére használják.

\section{Foveal-játék (EFAR)}

Ez egyszerre három játék folytatását jelenti:

Egy stratégiai szintű játékot, melyhez a FAR tervezte a szcenáriókat, egy taktikai szintű helyi játékot, melyhez konvencionális játékelméletet használhatunk, és a két szint közötti összhangot biztosítandó, egy harmadik játék is zajlik ${ }^{75}$.

Az EFAR-t üzleti stratégiai tervezéshez is használják. Az EFAR kimenete a szcenáriók alkotta háló, és ezek időbeli fejlődése visszakövethető. Iterációval egyeztetés és intézkedési tervek készítése bármely lépésnél lehetséges ${ }^{76}$. Állapotátmenetek speciális elemzése megengedett. A stratégiai és taktikai szintű döntések összehangolását segíti: mivel ezek egymás játékterét szűkíthetik, a taktikai/helyi döntések előtt ellenőrzést végez.

\section{Powergraph}

Ez a technika szelektíven mutatja egy operatív vagy taktikai döntéshozónak az előtte álló választási lehetőségeket (mintegy döntési fa szerűen). Iterative használják $k^{77}$.

Modelljében megjelennek a játékosok, a jövő szcenáriói alkotta háló, a játékosok szcenáriópreferenciái, az, hogy kinek áll hatalmában elérni egy állapotátmenetet, az állapotok preferencia-sorrendje játékosonként $^{78}$. Algoritmikusan két dolgot hajt végre:

- meghatároz motivált hatalmat és feltárja a várható fejlődést, valamint

- kiválasztja a fejlődés spontán menetébe való beavatkozási változatokat a hatalmi viszonyok és motiváció változásai, a veszélyhelyzeti tervek figyelembevételével, hogy mindebből egy intézkedési tervet alakítson $\mathrm{ki}^{79}$.

\section{Felhasznált irodalom}

Alpern, S. (1993): Stationary equilibria for deterministic graphical games, in: Binmore ed.: Frontiers of game theory, Cambridge MA: MIT Press

Ashby, W. (1952): A Design for a Brain, New York: John Wiley and Sons

Arrow, K. (1951): Social Choice and Individual Values, Wiley NY Bacharach, M. (1993): Variable Universe Games, in: Binmore ed.: Frontiers of game theory, Cambridge MA: MIT Press

Barclay, S. (1988): A user manual to EQUITY, DA Unit, London School of Economics

Bárdossy, Gy. - Fodor, J. (2004): Evaluation of Uncertainties and Risks in Geology, Springer, p. 32

Beattie, C. J.(1970) Allocating resources to research in practice, NATO conf. On Applications of Mathematical Programming, Cambridge

Belardo, S. - Harrald, J. (1992): A framework for the application of group decision support systems to the problem of planning for catastrophic events, IEEE Transactions on Engineering Management, November

Bennett, P. G. (1989): Modeling interactive decisions: the hypergame focus, in: Rosenhead ed: Rational Analysis for a problematical world, Chicester: J. Wiley

Bennett, P. G. - van Heeswijk, S. (1997): Using software for confrontation analysis: a case study in food safety policy, Working paper at IMA conference at Waldham College April

Brams, S. J. (1994): Theory of moves, Cambridge: CUP

Bryson, K. M. - Millar, H. - Joseph, A. - Mobolurin, A. (2002): Using formal MS/OR modeling to support disaster recovery planning, European Journal of Operational Research 141, pp. 679-688.

Chrichton, M. - Flinn, R. (2002): Command decision making, in:R.Flin, K.Arbuthnot eds.: Incident command: tales from the hot seat, Ashgate Publishing Company, England 2002, pp. 201238

Coyle, R. G. - Crawshay, R. - Sutton, L. (1994): Futures assessment by field anomaly relaxation, Futures, Vol. 26. No. 1. pp. 25-43.

Coyle, R. G. - Powell, J. H. (1997): A network based approach to strategic business planning, JORS, Vol.48. No. 8. pp. 793-803.

Coyle, R. G. - McGlone, R. (1997): Projecting scenarios for SE Asia and the SW Pacific, Futures, 27 (1) pp. 65-79.

Crecine, J. P. (1969): Govenmental Problem Solving, Chicago: Rand McNally \& Co.

Cyert, R. M. - March, J. G. (1963): A Behavioral Theory of the Firm, Englewood Cliffs, N. J.: Prentice-Hall, Inc.

Daniels, J. D. (1987): Artificial Intelligence: A Brief Tutorial, in: S. J. Andriole: AI and national defence: Applications to C3I and beyond, AFCEA Washington D. C. pp. 3-12.

Defence Intelligence Agency Methodology Catalog (1986): An aid to intelligence analysts and forecasters, Chapter II, DDE-2200227-86 November

Dempster, A. P. (1967): Upper and lower probabilities induced by a multivalued mapping, Annals of Mathematical Statistics No.38. pp. 325-339

Dewar, J. A. - Levin, M. H. (1992): Assumption-based planning for Army 21, RAND p.7

Downs, A. (1967): Inside Bureaucracy, Boston: Little, Brown \& Co.

Esch, M. E. (1965): Planning assistance through technical evaluation of relevance numbers, Proc. of the 17th National Aerospace Electronics Conf., Dayton, Ohio, 10-12 May, IEEE, New York

Fraser, N. M. - Hipel, K. W. (1984): Conflict analysis: models and resolutions, Amsterdam: North Holland

Fudenberg, D. - Tirole, J. (1993):Game Theory, Cambridge MA: MIT Press 
Goodwin, P. - Wright, G. (1998): Decision analysis for management judgement, Wiley \& Sons

Habermas, J. (1990): Moral consciousness and communicative action, Cambridge: Polity Press

Harsanyi, J. (1992): Normative validity and meaning of Neumann and Morgenstern utilities, in: Skyrms ed: Studies in logic and the foundations of game theory, Dordrecht: Reidel

Hirschleifer, J. - Riley, J. G. (1992)The analytics of uncertainty and information, Cambridge: Cambridge UP

Howard, N. (1994): Drama theory and its relationships to game theory, Group Decision and Negotiation 1994, 3 pp. 187-206, 207-253.

Howard, N. (1997): Drama theory: fundamental theorems, Proc. Conf. IMA at Waldham College April

Jackson, J. (1971): Statistical Models of Senate Roll Call Voting, American Political Science Review, Vol. 65. June

Jones, P. M. S. (1969): Technological forecasting as a management tool, P. A. U. M10, HMSO London

Karkar, H. (1991): Mirror effects, metagames and crisis, in: M. Rudnianski, R.Avenhaus, H. Karkar, Defence decision making

Levine, P. - Pomerol, J. C. H. (1989): Negotiation support systems: an overview and some knowledge-based examples, in: Ravenhaus, H. - Karkar, M. - Rudnianski, (eds.) (1991): Proceedings of the 1st ARESAD International Conference on Decision Making and Defence, Paris, Nov 22-23. 1989. Springer Verlag

Ling, X. - Rudd, W. G. (1989): Combining Opinions from several experts, Applied AI Vol. 3.

PSP 9908 G. M. Marshall Center, Conflict Resolution and Prevention Seminar, 25-29 January 1999, p. H-2

Liu, X. (1999): A spatial supergame model of bilateral interactions: the case of US-China relations, $\mathrm{PhD}$ thesis Texas A\&M University, College Station

Mezey Gy. (2002): Előrejelzés és a mesterséges intelligencia lehetőségei, NEK ZMNE VI. évf. 2. szám 123-132. o.

Mintz, A. - Geva, N. - Redd, S. B. - Carnes, A. (1997): The effect of dynamic and static choice sets on political decision-making: an analysis using the decision board platform, American Political Science Review 91 (3), pp. 553-566.

Olson, M. (1965): The Logic of Collective Action, Cambridge, Mass.: Harvard Univ. Press

Powell, J. H. (1997): A network-based framework for strategic conflict resolution, PhD thesis Cranfield Univ. 1997

Powell, J. H. (1997): An application of a network-based futures method to strategic business planning, JORS, Vol. 48. No.7. pp. 857-872.

Rhyne, R. (1981): Whole pattern futures projection using field anomaly relaxation, Technological Forecasting and Social Change, 19, pp. 331-360.

Richardson, G. P. - Rohrbaugh, J. (1989): Decision making in dynamic environments: exploring judgements in a system dynamics model based game, in: K. Borcherding, O. I. Larichev, D. M. Messick eds.: Contemporary Issues in Decision Making, Elsevier, Amsterdam

Saaty, T. L. (1990): The analytic hierarchy process, RWS Publications, Pittsburgh

Sántáné Tóth Edit (2000): Tudásalapú technológia, szakértői rendszerek, Főiskolai Kiadó

Schwartz, P. (1991): The art of the long view, New York: Doubleday, pp.7-10.

Shakun, M. F. (1986): Group Decision and Negotiation Support in Evolving, Nonshared Information Contexts, Cahier du LAMSADE No 89

Shubik, M. (1983): Mathematics of Conflict, Amsterdam: Elsevier

Sweets, J. A. - Tanner, W. P. - Birdsall, T. G. (1968): Decision Process in Perception, New York: Holt, Rinehart \& Winston

Temesi J. (2002): A döntéselmélet alapjai, Budapest, Aula

Turban, E. (1995): Decision support and expert systems, management support systems, Prentice Hall Intl. Inc.
Whittington, $R$. (1995): What is strategy and does it matter? London: Routledge

Yong, Y. C. (1994): Creating coherent appreciation with Field Anomaly Relaxation, MSc. dissertation RMCS University of Cranfield

Zoltayné Paprika Z. (2002): Döntéselmélet, Budapest, Alinea

Zwichy, F. (1942): Morfologische Forschung, Winterthur: Winterthur A. G.

\section{Jegyzetek}

Temesi J., A döntéselmélet alapjai, (Budapest Aula 2002) p. 37.

${ }^{2}$ PSP 9908 G.M.Marshall Center, Conflict Resolution and Prevention Seminar, (25-29 January 1999) p. H-2

3 Temesi J., A döntéselmélet alapjai, (Budapest Aula 2002) p. 158159.

${ }^{4}$ Zoltayné Paprika Z, Döntéselmélet, (Budapest, Alinea 2002) p. 250.

5 Zoltayné Paprika Z, Döntéselmélet, (Budapest, Alinea 2002) p. 527.

P. Levine, J. C. Pomerol, Negotiation Support systems: an overview and some knowledge-based examples, (in: R. Avenhaus, H. Karkar, M. Rudnianski, eds.: Proceedings of the 1st ARESAD International Conference on Decision Making and Defence, Paris, Nov 22-23. 1989. Springer Verlag 1991) p. 241. J. D. Daniels, Artificial Intelligence: A Brief Tutorial, (in: S. J. Andriole: AI and national defence: Applications to C3I and beyond, AFCEA Washington D. C. 1987) pp. 3-12.

${ }^{8}$ PSP 9908 G.M.Marshall Center, Conflict Resolution and Prevention Seminar, (25-29 January 1999) p. H-8, H-11

9 Zoltayné Paprika Z, Döntéselmélet, (Budapest, Alinea 2002) p. 298. definiálja a BSC (British Computer Society)

${ }^{10}$ Temesi J., A döntéselmélet alapjai, (Budapest, Aula 2002) p. 3741. A. P. Dempster, Upper and lower probabilities induced by a multivalued mapping, (Annals of Mathematical Statistics No. 38. 1967) pp. 325-339.

${ }^{11}$ Gy. Bárdossy, J. Fodor, Evaluation of Uncertainties and Risks in Geology, (Springer 2004) p. 32.

${ }^{12}$ X. Ling, W. G. Rudd, Combining Opinions from several experts, (Applied AI Vol. 3, 1989)

${ }^{13}$ Sántáné Tóth Edit, Tudásalapú technológia, szakértői rendszerek (Főiskolai Kiadó 2000) 162-166. o.

${ }^{14}$ M. F. Shakun, Group Decision and Negotiation Support in Evolving, Nonshared Information Contexts, (Cahier du LAMSADE No 89, 1986)

S Sántáné Tóth Edit, Tudásalapú technológia, szakértői rendszerek (Főiskolai Kiadó 2000) 123. o.

${ }^{16}$ P. Levine, J - C. H. Pomerol, Negotiation support systems: an overview and some knowledge based examples, (in: R. Avenhaus, H. Karkar, M. Rudnianski eds.: Defence Decision Making, Proceedings of the 1st ARESAD International Conference on Decision Making and Defence, Paris, Nov 22-23. 1989. Springer Verlag 1991) pp. 241-256.

${ }^{17}$ Y. C. Yong, Creating coherent appreciation with Field Anomaly Relaxation, (MSc. dissertation RMCS,

${ }^{18}$ University of Cranfield 1994)

${ }^{19}$ Belardo S., Harrald J., A framework for the application of group decision support systems to the problem of planning for catastrophic events, (IEEE Transactions on Engineering Management, November 1992)

${ }^{20}$ E. Turban, Decision support and expert systems, management support systems, (Prentice Hall Intl. Inc. 1995

${ }^{21}$ E. Turban, Decision support and expert systems, management support systems, (Prentice Hall Intl. Inc. 1995

${ }^{22}$ E. Turban, Decision support and expert systems, management support systems, (Prentice Hall Intl. Inc. 1995

${ }^{23}$ M. Chrichton, R. Flinn, Command decision making, (in: R. Flin, 
K. Arbuthnot eds.: Incident command: tales from the hot seat, Ashgate Publishing Company, England 2002), pp. 201-238.

${ }^{24}$ K. M. Bryson, H. Millar, A. Joseph, A. Mobolurin, Using formal MS/OR modeling to support disaster recovery planning, (European Journal of Operational Research 141 2002), pp. 679-88.

${ }^{25}$ Defence Intelligence Agency Methodology Catalog, An aid to intelligence analysts and forecasters, (Chapter II, DDE-2200227-86 November 1986)

${ }^{26}$ C. J. Beattie, Allocating resources to research in practice, (NATO conf. On Applications of Mathematical Programming, Cambridge, UK (EUP) 1970)

${ }^{27}$ F. Zwichy: Morfologische Forschung, Winterthur: Winterthur A. G., Switzerland 1942

${ }^{28}$ Mezey Gy., Előrejelzés és a mesterséges intelligencia lehetőségei, (NEK ZMNE 2002 VI. évf. 2. szám 123-132. o.

${ }^{29}$ J. A. Dewar, M. H. Levin: Assumption-based planning for Army 21, RAND 1992 p.7

${ }^{30}$ P. M. S. Jones, Technological forecasting as a management tool, (P.A.U.M10, HMSO London 1969)

${ }^{31}$ M. E. Esch: Planning assistance through technical evaluation of relevance numbers, Proc. of the 17th National Aerospace Electronics Conf., Dayton, Ohio, 10-12. May 1965 IEEE, New York

${ }^{32}$ P. Schwartz, The art of the long view, (New York: Doubleday, 1991) pp. 7-10.

${ }^{33}$ R.M.Cyert, J.G.March, A Behavioral Theory of the Firm, (Englewood Cliffs, N, J, Prentice-Hall, Inc., 1963)

${ }^{34}$ J. P. Crecine, Govenmental Problem Solving, (Chicago: Rand McNally \& Co. 1969)

35 J. Jackson, Statistical Models of Senate Roll Call Voting, (in: American Political Science Review, Vol. 65. June 1971)

${ }^{36}$ P. Goodwin, G. Wright, Decision analysis for management judgement, (Wiley \& Sons 1998) pp. 360-383.

${ }^{37}$ P. Goodwin, G. Wright, Decision analysis for management judgement, (Wiley \& Sons 1998) p. 441-448.

${ }^{38}$ P. Goodwin, G.Wright, Decision analysis for management judgement, (Wiley \& Sons 1998) p. 330.

${ }^{39}$ K. J. Arrow, Social Choice and Individual Values, (Wiley NY 1951)

${ }^{40}$ W. Ashby, A Design for a Brain, (New York: John Wiley and Sons Inc. 1952) p. 76. ( ,joined systems”)

${ }^{41}$ A. Mintz, N. Geva, S. B. Redd, A. Carnes, The effect of dynamic and static choice sets on political decision-making: an analysis using the decision board platform, (American Political Science Review 91 (3) 1997) 553-566 p. 554.

${ }^{42}$ Zoltayné Paprika Z, Döntéselmélet, (Budapest, Alinea 2002) p. 209.

${ }^{43}$ G. P. Richardson, J. Rohrbaugh, Decision making in dynamic environments: exploring judgements in a system dynamics model based game, (in: K. Borcherding, O. I. Larichev, D. M. Messick eds.: Contemporary Issues in Decision Making, Elsevier, Amsterdam 1989)

${ }^{44}$ Zoltayné Paprika Z, Döntéselmélet, (Budapest, Alinea 2002) p. 324.

${ }^{45}$ J. Harsanyi, Normative validity and meaning of Neumann and Morgenstern utilities, (in: Skyrms ed: Studies in logic and the foundations of game theory, Dordrecht: Reidel 1992)

${ }^{46}$ Zoltayné Paprika Z, Döntéselmélet, (Budapest, Alinea 2002) p. 323.

${ }^{47}$ Zoltayné Paprika Z, Döntéselmélet, (Budapest, Alinea 2002) p. 250.

${ }^{48}$ M. Shubik, Mathematics of Conflict, (Amsterdam: Elsevier 1983)

${ }^{49}$ A. Downs, Inside Bureaucracy, (Boston: Little, Brown\&Co. 1967)

${ }^{50}$ M. Olson, The Logic of Collective Action, (Cambridge, Mass.: Harvard Univ. Press 1965)
${ }^{51}$ J. A. Sweets, W. P. Tanner, T. G. Birdsall, Decision Process in Perception, (New York: Holt, Rinehart \& Winston, 1968) pp. 78101.

${ }^{52} \mathrm{~S}$. Barclay, A user manual to EQUITY, (DA Unit, London School of Economics 1988)

${ }^{53}$ P. Goodwin, G. Wright, Decision analysis for management judgement, (Wiley \& Sons 1998) p. 134.

${ }^{54}$ P. Goodwin, G. Wright, Decision analysis for management judgement, (Wiley\&Sons 1998) p. 135.

55 J. H. Powell, A network-based framework for strategic conflict resolution, (PhD thesis Cranfield Univ. 1997) pp. 96-98.

${ }^{56}$ J. Hirschleifer, J. G. Riley, The analytics of uncertainty and information, (Cambridge: Cambridge UP 1992)

${ }^{57}$ D. Fudenberg, J. Tirole, Game Theory, (Cambridge MA: MIT Press 1993)

${ }^{58}$ M. Bacharach, Variable Universe Games, (in: Binmore ed.: Frontiers of game theory, Cambridge MA: MIT Press 1993)

${ }^{59}$ S. J. Brams, Theory of moves, (Cambridge: CUP 1994) p. 215219.

${ }^{60} \mathrm{~S}$. Alpern, Stationary equilibria for deterministic graphical games, (in: Binmore ed.: Frontiers of game theory, Cambridge MA: MIT Press 1993)

${ }^{61} \mathrm{X}$. Liu, A spatial supergame model of bilateral interactions: the case of US-China relations, $\mathrm{PhD}$ thesis

${ }^{62}$ Texas A\&M University, College Station, Texas 1999)

${ }^{63}$ P. G. Bennett, Modeling interactive decisions: the hypergame focus, (in: Rosenhead ed: Rational Analysis for a problematical world, Chicester: J. Wiley, 1989)

${ }^{64}$ H. Karkar, Mirror effects, metagames and crisis, (in: M. Rudnianski, R. Avenhaus, H. Karkar, Defence decision making 1991) pp. 257-271.

${ }^{65}$ N. M. Fraser, K. W. Hipel, Conflict analysis: models and resolutions, (Amsterdam: North Holland, 1984)

${ }^{66} \mathrm{R}$. Whittington, What is strategy and does it matter? (London: Routledge 1995)

${ }^{67}$ J. Habermas, Moral consciousness and communicative action, (Cambridge: Polity Press 1990)

${ }^{68}$ N. Howard, Drama theory and its relationships to game theory, (Group Decision and Negotiation 1994, 3) p. 187-206, 207-253.

${ }^{69}$ N. Howard, Drama theory: fundamental theorems, (Proc. Conf. IMA at Waldham College April 1997)

${ }^{70}$ P. G. Bennett, Modeling interactive decisions: the hypergame focus, (in: Rosenhead ed: Rational Analysis for a problematical world, Chicester: J. Wiley 1989)

P. G. Bennett, van S. Heeswijk, Using software for confrontation analysis: a case study in food safety policy, (Working paper at IMA conference at Waldham College April 1997)

${ }^{2}$ R. Rhyne, Whole pattern futures projection using field anomaly relaxation, (Technological Forecasting and Social Change 1981, 19) pp. 331-360.

${ }^{73}$ T. L. Saaty, The analytic hierarchy process, (RWS Publications, Pittsburgh 1990)

${ }^{74}$ R. G. Coyle, R. McGlone, Projecting scenarios for SE Asia and the SW Pacific, (Futures 1997, 27 (1) pp. 65-79.

${ }^{75}$ R. G. Coyle, R. Crawshay, L. Sutton, Futures assessment by field anomaly relaxation, (Futures, 1994, Vol. 26. No1) p. 25-43.

${ }^{76}$ J. H. Powell, An application of a network-based futures method to strategic business planning, (JORS 1997. Vol. 48. No7) pp. 857-872.

${ }^{77}$ R. G. Coyle, J . H. Powell, A network based approach to strategic business planning, (JORS 1997 Vol. 48. No8) pp. 793-803.

${ }^{8}$ J. H. Powell, A network-based framework for strategic conflict resolution, (PhD thesis Cranfield Univ. 1997) p. 239.

79 J. H. Powell, A network-based framework for strategic conflict resolution, (PhD thesis Cranfield Univ. 1997) p. 258. 